\title{
Improvement of Phencyclidine-Induced Cognitive Deficits in Mice by Subsequent Subchronic Administration of Fluvoxamine, but not Sertraline
}

\author{
Tamaki Ishima ${ }^{1}$, Yuko Fujita ${ }^{1}$, Mami Kohno ${ }^{1}$, Shinsui Kunitachi ${ }^{1}$, Mao Horio ${ }^{1}$, Yuto Takatsu ${ }^{1}$, \\ Takahiko Minase $^{1}$, Yuko Tanibuchi ${ }^{1,2}$, Hiroko Hagiwara ${ }^{1,2}$, Masaomi Iyo ${ }^{2}$ and Kenji Hashimoto ${ }^{1, *}$ \\ ${ }^{I}$ Division of Clinical Neuroscience, Chiba University Center for Forensic Mental Health, Chiba 260-8670, Japan, and \\ ${ }^{2}$ Department of Psychiatry, Chiba University Graduate School of Medicine, Chiba 260-8670, Japan
}

\begin{abstract}
This study was undertaken to examine the effects of the two selective serotonin reuptake inhibitors (SSRIs: fluvoxamine and sertraline) with a high affinity at sigma-1 receptors on cognitive deficits in mice after repeated administration of the N-methyl-D-asparatte (NMDA) receptor antagonist phencyclidine (PCP). In the novel object recognition test (NORT), PCP (10 mg/kg/day, 10 days)-induced cognitive deficits in mice were significantly improved by subsequent subchronic (14 days) administration of fluvoxamine $(20 \mathrm{mg} / \mathrm{kg} / \mathrm{day})$, but not sertraline (10 or $20 \mathrm{mg} / \mathrm{kg} / \mathrm{day})$. Western blot analysis revealed that repeated administration of PCP $(10 \mathrm{mg} / \mathrm{kg} / \mathrm{day}, 10$ days $)$ caused the reduction of sigma- 1 receptors in the frontal cortex and hippocampus of mouse brain. These findings suggest that repeated administration of PCP caused the reduction of sigma- 1 receptors in the mouse brain, and that sigma- 1 receptor agonists such as fluvoxamine may be useful for treatment of cognitive deficits in schizophrenia.
\end{abstract}

\section{INTRODUCTION}

Cognitive deficits in patients with schizophrenia are core features of the illness, and predict vocational and social disabilities for patients [1]. Multiple lines of evidence suggest that a dysfunction in glutamatergic neurotransmission via the $\mathrm{N}$-methyl-D-aspartate (NMDA) receptors might be involved in the pathophysiology of schizophrenia [2-11]. The NMDA receptor antagonists such as phencyclidine (PCP) are known to induce schizophrenia-like symptoms including cognitive deficits and negative symptoms in healthy subjects [2]; consequently, PCP has been used widely in animal models of cognitive deficits in schizophrenia [2, 12-17]. We reported that, in the novel object recognition test (NORT), PCPinduced cognitive deficits could be improved by subsequent subchronic (14 days) administration of clozapine, but not haloperidol, suggesting that reversal of PCP-induced cognitive deficits using the NORT may be a potential animal model of atypical antipsychotic activity in relation to amelioration of cognitive deficits in schizophrenia [12].

Accumulating evidence suggests that the endoplasmic reticulum protein sigma-1 receptors play a role in the pathophysiology of neuropsychiatric diseases such as schizophrenia, anxiety disorders, and depression as well as in the evolution of cognitive deficits associated with these conditions [18-25]. We previously reported that some of selective serotonin reuptake inhibitors (SSRIs) possess high to moderate affinity for sigma-1 receptors [26]. Among the SSRIs, fluvoxamine was the most potent $(\mathrm{Ki}=36 \mathrm{nM})$ for sigma-1 receptors, and sertraline was also the potent $(\mathrm{Ki}=57 \mathrm{nM})$ for

\footnotetext{
*Address correspondence to this author at the Division of Clinical Neuroscience, Chiba University Center for Forensic Mental Health, Chiba 2608670, Japan; E-mail: hashimoto@ faculty.chiba-u.jp
}

sigma-1 receptors [26]. Recently, we reported that, in NORT, PCP-induced cognitive deficits could be significantly improved by subsequent subchronic (14 days) administration of sigma-1 receptor agonists (fluvoxamine, SA4503, and dehydroepiandrosterone 3-sulfate (DHEA-S)), and that the effects of these sigma-1 receptor agonists was significantly antagonized by co-administration of the selective sigma-1 receptor antagonist NE-100 [13]. These findings suggest that agonistic activity of fluvoxamine at sigma- 1 receptors plays a role in the active mechanisms of fluvoxamine on PCP-induced cognitive deficits in mice [13].

The present study was undertaken whether another SSRI sertraline with high affinity for sigma-1 receptors could improve PCP-induced cognitive deficits in mice. Furthermore, we studied the effects of repeated PCP administration on the levels of sigma-1 receptors in mouse brain.

\section{MATERIALS AND METHODS}

\section{Animals}

Male ICR mice (6 weeks old) weighing 25-30 g were purchased from SLC Japan (Hamamatsu, Shizuoka, Japan). Mice in groups of 4 or 5 were housed in clear polycarbonate cages $(22.5 \times 33.8 \times 14.0 \mathrm{~cm})$ under a controlled 12/12-h lightdark cycle (light from 7:00 AM to 7:00 PM), at $23 \pm 1^{\circ} \mathrm{C}$ and $55 \pm 5 \%$ humidity. The mice were given free access to water and food pellets. The experimental procedure was approved by the Animal Care and Use Committee of Chiba University.

\section{Materials}

PCP hydrochloride was synthesized in our laboratory. Fluvoxamine maleate and sertraline hydrochloride were ob- 
tained from Solvay Seiyaku K.K., (Tokyo, Japan) and Toronto Research Chemicals Inc. (North York, ON, Canada), respectively. Other drugs were purchased from commercial sources. The doses of fluvoxamine $(20 \mathrm{mg} / \mathrm{kg})$ and sertraline (10 or $20 \mathrm{mg} / \mathrm{kg}$ ) had been shown to be effective in vivo as reported previously $[13,27]$.

\section{Drug Administration}

Saline $(10 \mathrm{ml} / \mathrm{kg})$ or PCP $(10 \mathrm{mg} / \mathrm{kg}$ expressed as a hydrochloride salt) was administered subcutaneously (s.c.) for 10 days (once daily on days $1-5,8-12$ ) as reported previously [12-17]. In the subchronic (14 days) administration experiment, three days (day 15) after the final administration of saline or PCP, vehicle or drugs was administered i.p. into mice. This treatment was continued for 14 consecutive days (once daily on days 15-28). The training session of the NORT was performed 24 hours after the final administration, and the retention test session was performed 24 hours after the training session as described below.

\section{Novel Object Recognition Test (NORT)}

NORT was performed as previously reported [12-17]. The apparatus for this task consisted of a black open field box $(50.8 \times 50.8 \times 25.4 \mathrm{~cm})$. Before the test, mice were habituated in the box for 3 days. During a training session, two objects (various objects differing in shape and color but similar in size) were placed in the box $35.5 \mathrm{~cm}$ apart (symmetrically), and each animal was allowed to explore in the box for 5 minutes. The animals were considered to be exploring the object when the head of the animal was facing the object within $2.54 \mathrm{~cm}$ of the object or when any part of the body, except for the tail, was touching the object. The time that mice spent exploring each object was recorded. After training, mice were immediately returned to their home cages, and the box and objects were cleaned with $75 \%$ ethanol to avoid any possible instinctive odorant cues. Retention tests were carried out at one-day intervals following the respective training. During the retention test each mouse was placed back into the same box in which one of the objects used during training was replaced by a novel one. The mice were then allowed to explore freely for 5 minutes, and the time spent exploring each object was recorded. Throughout the experiments, the objects were used in a counter-balanced manner in terms of their physical complexity and emotional neutrality. A preference index, i.e., the ratio of the amount of time spent exploring any one of the two objects (training session) or the novel one (retention test session) over the total time spent exploring respective to both objects, was used to measure memory performance.

\section{Western Blotting}

Saline $(10 \mathrm{ml} / \mathrm{kg} / \mathrm{day})$ or PCP $(10 \mathrm{mg} / \mathrm{kg} /$ day $)$ was administered s.c. for 10 days (once daily on days 1-5, 8-12). Three days (days 15) after the final administration of saline or PCP (10 mg/kg/day for 10 days), mice were sacrificed by decapitation. Then, frontal cortex and hippocampus were dissected on ice, and stored at $-80^{\circ} \mathrm{C}$.

Briefly, brain tissue was homogenized in $10 \mathrm{vol}$ of $5 \mathrm{mM}$ Tris/ $\mathrm{HCl}$ ( $\mathrm{pH} 7.4$ ) containing $0.32 \mathrm{M}$ sucrose and centrifuged for $10 \mathrm{~min}$ at $1,000 \mathrm{xg}$. The resulting supernatant was recentrifuged for $10 \mathrm{~min}$ at $40,000 \mathrm{x} \mathrm{g}$ to obtain the crude mem- brane fraction. The pellet was washed twice in buffer and resuspended in the solution including $0.1 \mathrm{mg} / \mathrm{mL}$ aprotinin, $0.1 \mathrm{mg} / \mathrm{mL}$ pepstatin, $2.5 \mu \mathrm{g} / \mathrm{mL}$ phenylmethylsulfonyl fluoride, and $1 \%$ Tween 20 . Aliquots (50 $\mu \mathrm{g}$ protein) of the membranes were incubated for $5 \mathrm{~min}$ at $95^{\circ} \mathrm{C}$ with an equal volume of $125 \mathrm{mM}$ Tris/ $\mathrm{HCl}, \mathrm{pH} 6.8,20 \%$ glycerol, $0.1 \%$ bromphenol blue, $10 \% \beta$-mercaptoethanol, 4\% SDS, and subjected to SDS-PAGE using 10\% mini-gels (Mini Protean II; Bio-Rad, Hercules, CA, USA). Proteins were transferred onto PVDF membranes using a Trans Blot Mini Cell (BioRad, Hercules, CA, USA). For immunodetection, the blots were blocked for 1-2 $\mathrm{h}$ in TBST (50 mM Tris/HCl, $\mathrm{pH} \mathrm{7.8,}$ $0.13 \mathrm{M} \mathrm{NaCl}, 0.1 \%$ Tween 20 ) containing $5 \%$ nonfat dry milk at room temperature (RT), followed by incubation with goat anti-sigma-1 receptor antibody (1:250, Cat. No: SC16203, Santa Cruz Biotechnology, Inc., Santa Cruz, CA, USA) overnight at $4^{\circ} \mathrm{C}$ in TBST $/ 5 \%$ blocker. The blots were washed five times with TBST. Incubation with the secondary antibody (Santa Cruz Biotechnology, Inc., Santa Cruz, CA, USA) was performed for $1 \mathrm{~h}$ at RT. After extensive washing, immunoreactivity was detected by ECL plus Western Blotting Detection system (GE Healthcare Bioscience, UK). Images were captured using a Fuji LAS3000-mini imaging system (Fujifilm, Tokyo, Japan), and immunoreactive bands were quantified. $\beta$-Actin immunoreactivity was used to monitor equal sample loading. The levels of sigma-1 receptors in the PCP-treated mice were expressed as a percentage of those of saline-treated mice (control).

\section{Statistical Analysis}

Data are expressed as means \pm S.E.M. Statistical analysis was performed using Student t-test or one-way analysis of variance analysis (ANOVA) and the post hoc Bonferroni test. The $p$ values less than 0.05 were considered statistically significant.

\section{RESULTS}

In the NORT, repeated administration of PCP (10 $\mathrm{mg} / \mathrm{kg} /$ day for 10 days) caused significant cognitive deficits in mice, consistent with previous reports [12-17]. We found that PCP-induced cognitive deficits were significantly improved after subsequent subchronic (14 days) administration of fluvoxamine $(20 \mathrm{mg} / \mathrm{kg} / \mathrm{day})$, but not sertraline (10 or 20 $\mathrm{mg} / \mathrm{kg} /$ day $)$. The effect of fluvoxamine $(20 \mathrm{mg} / \mathrm{kg})$ on PCPinduced cognitive deficits is consistent with a previous study [13].

In the training session, one-way ANOVA revealed that the exploratory preferences of five groups were not significantly different $(\mathrm{F}[4,72]=1.202, \mathrm{p}=0.317)$ (Fig. 1). However, one-way ANOVA did reveal significant differences in the exploratory preferences of the five groups in the retention test sessions $(\mathrm{F}[4,72]=14.27, \mathrm{p}<0.001)($ Fig. 1). The post hoc Bonferroni test indicated that the exploratory preference of the PCP plus vehicle-treated group was significantly $(\mathrm{p}<0.001)$ lower than that of the PCP plus fluvoxamine $(20 \mathrm{mg} / \mathrm{kg} / \mathrm{day})$-treated group, but not of groups treated with PCP plus sertraline (10 or $20 \mathrm{mg} / \mathrm{kg} /$ day) (Fig. 1). In contrast, there was no difference between vehicle-treated group and PCP plus fluvoxamine (20 mg/kg/day)-treated group although the difference failed to reach statistical significance $(p=0.065)$ (Fig. 1). 


\section{Training session 24 hrs $\longrightarrow$ Retention test session}
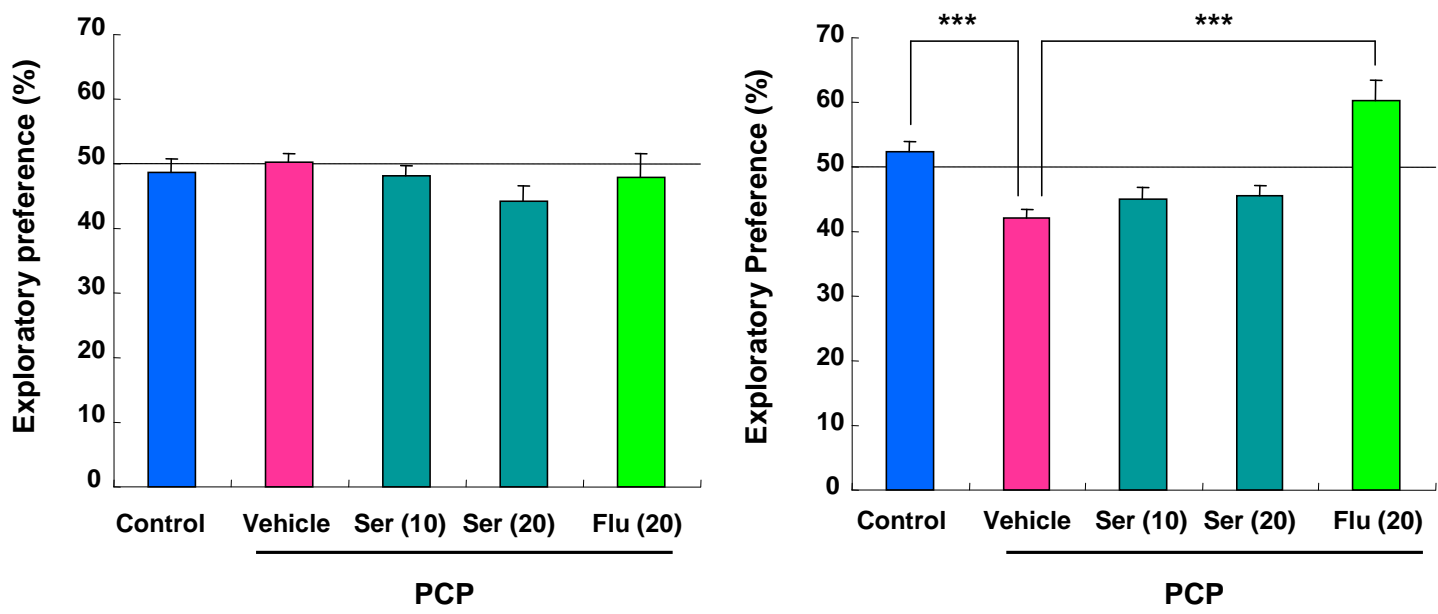

Fig. (1). Effects of fluvoxamine and sertraline on PCP-induced cognitive deficits in mice. Saline (10 ml/kg/day) or PCP (10 mg/kg/day) were administered s.c. for 10 days (once daily on days 1-5, 8-12). Three days (day 15) after the final administration of saline or PCP, vehicle $(10 \mathrm{ml} / \mathrm{kg} /$ day $)$, fluvoxamine $(20 \mathrm{mg} / \mathrm{kg} /$ day $)$, or sertraline $(10$ and $20 \mathrm{mg} / \mathrm{kg} / \mathrm{day})$ were administered i.p. into mice. The treatment was continued for 14 consecutive days (once daily on day 15-28). The training session for the novel object recognition test was performed 24 hrs (day 29) after the final administration of vehicle or drugs, and the retention test session was performed 24 hrs (day 30) after the training session. Values are means \pm S.E.M $(\mathrm{n}=9-24) . * * * \mathrm{p}<0.001$ as compared with PCP-treated group.

Next we examined whether repeated PCP administration alters the density of sigma-1 receptors in the mouse brain. Western blot analysis revealed that levels of sigma-1 receptors in the frontal cortex $(\mathrm{t}=4.987, \mathrm{p}=0.001)$ and hippocampus $(\mathrm{t}=3.482, \mathrm{p}=0.006)$ of the PCP $(10 \mathrm{mg} / \mathrm{kg} / \mathrm{day}$ for 10 days)-treated mice were significantly lower than those of saline-treated mice (Fig. 2).

\section{DISCUSSION}

The major findings of the present study are that repeated PCP administration significantly decreased the density of sigma-1 receptors in mouse brain, and that PCP-induced cognitive deficits could be improved by subsequent sub-

\section{Frontal Cortex}

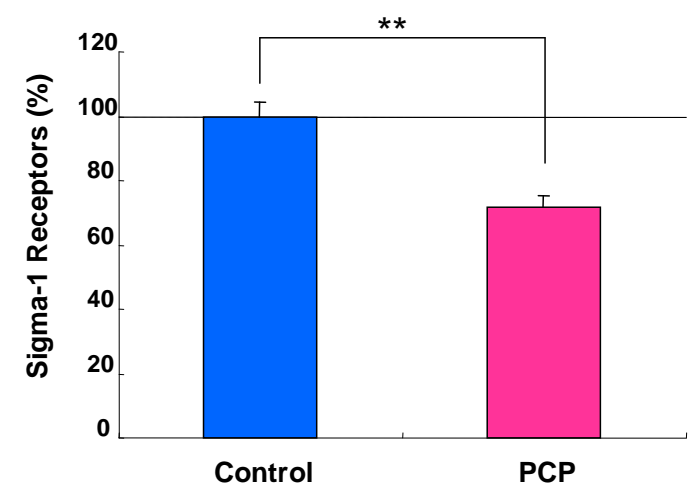

chronic (14 days) administration of fluvoxamine, but not sertraline. Recently, we reported that, in the NORT, PCPinduced cognitive deficits could be significantly improved by subsequent subchronic (14 days) administration of fluvoxamine, and that the effect of fluvoxamine was significantly antagonized by co-administration of the selective sigma-1 receptor antagonist NE-100, suggesting the role of sigma-1 receptor agonism in the mechanism of action of fluvoxamine [7]. Unlike to fluvoxamine, sertraline (SSRI with a high affinity at sigma-1 receptors) did not attenuate the PCP-induced cognitive deficits in mice. The reason underlying this discrepancy between two SSRIs is currently unclear. One possibility may be due to the difference for pharmacological actions (agonist or antagonist) of two

\section{Hippocampus}

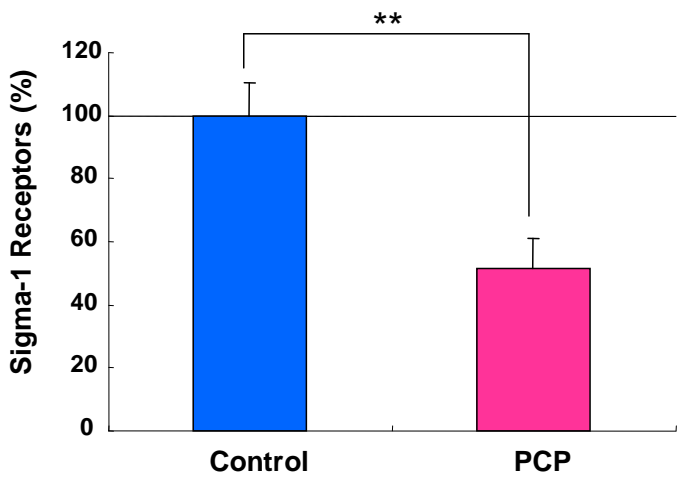

Fig. (2). Effects of repeated administration of PCP on sigma-1 receptor protein in mouse brain. Saline $(10 \mathrm{ml} / \mathrm{kg} / \mathrm{day}) \mathrm{or} \mathrm{PCP}(10$ $\mathrm{mg} / \mathrm{kg} /$ day) were administered s.c. for 10 days (once daily on days 1-5, 8-12). Three days (days 15) after the last administration of saline or PCP, mice were sacrificed by decapitation. Western blot analysis using goat anti-sigma-1 receptor antibody was performed as described in Methods. The levels of sigma-1 receptors in the PCP-treated mice were expressed as a percentage of those of saline-treated mice. Values are the mean \pm S.E.M $(n=6) . * * p<0.01$ as compared with saline-treated group (Control). 
SSRIs at sigma-1 receptors. Takebayashi et al. [28] reported that antidepressants including fluvoxamine significantly could enhance nerve growth factor (NGF)-induced neurite sprouting in PC12 cells, and that NE-100 blocked the enhancements by these antidepressants, suggesting the role of sigma-1 receptor agonism in the mechanism of action of fluvoxamine [28]. Recently, we found that, unlike to fluvoxamine, sertraline did not enhance the NGF-induced neurite sprouting in PC12 cells [29]. These finings suggest that fluvoxamine and sertraline may exert as an agonist and an antagonist at sigma-1 receptors, respectively [29]. Taken together, it is likely that the discrepancy of pharmacological action (agonist vs. antagonist) for sigma-1 receptors might contribute to the discrepancy of these two SSRIs on PCPinduced cognitive deficits although a further detailed study is necessary.

Another possibility may be due to anti-cholinergic effect of sertraline. It is known that, unlike to fluvoxamine $(\mathrm{Ki}=$ $31,200 \mathrm{nM}$ ), sertraline binds to muscarinic receptors with a moderate affinity $(\mathrm{Ki}=427 \mathrm{nM})[23,30]$. Potent anticholinergic activity may produce the unpleasant side effects including cognitive deficits and memory loss [23, 24]. Thus, it is likely that anti-cholinergic activity of sertaline may play a role in the mechanism of lack of this drug on PCP-induced cognitive deficits in mice.

In this study, we found that repeated PCP administration caused the reduction of sigma- 1 receptors in mouse brain. This is the first report demonstrating that administration of PCP significantly decreased the density of sigma- 1 receptors in the brain. It is well known that sigma- 1 receptors might modulate the NMDA receptors in the brain $[18,19,21,22$, $24,31]$. However, the precise mechanism(s) underlying how repeated PCP administration could modulate sigma-1 receptors in the brain are currently unknown. Postmortem human brain study demonstrated decreased expression of cerebral cortical sigma-1 receptors in schizophrenic patients [32], suggesting that decreased levels of sigma-1 receptors in brain with schizophrenic patients may be implicated in the cognitive deficits of schizophrenia. Recently, we reported a case that adjunctive therapy of fluvoxamine improved cognitive impairments in a schizophrenic patient [33]. In addition, a brain imaging study using positron emission tomography demonstrated that fluvoxamine binds to sigma-1 receptors in intact human brain, suggesting that sigma-1 receptors play a role in the mechanism of action of fluvoxamine [34]. Therefore, it is likely that sigma-1 receptor agonism of fluvoxamine may be involved in the mechanism of action of this drug on cognitive deficits in schizophrenia [35].

\section{CONCLUSIONS}

The present study suggests that the adjunctive medication of sigma-1 receptor agonists such as fluvoxamine might potentially be used for the treatment of cognitive deficits of schizophrenia. A double-blinded, placebo-controlled study of fluvoxamine in schizophrenic patients is currently underway at Chiba University Hospital.

\section{ACKNOWLEDGEMENTS}

This study is partly supported by a grant from the Ministry of Education, Culture, Sports, Science, and Technology of Japan (to K.H.).

\section{CONFLICT OF INTEREST}

Ms. Ishima, Ms. Fujita, Ms. Kohno, Mr. Kunitachi, Ms. Horio, Mr. Takatsu, Mr. Minase, Ms. Hagiwara and Dr. Tanibuchi report no competing interests. Dr. Iyo reports receiving the speaker fees from Janssen, Meiji Seika, Asteras, Dainippon-Sumitomo, GlaxoSmithKline, Novartis, Eli Lilly, Pfizer, and Otsuka. Dr. Hashimoto reports receiving the speaker fees from Solvay, Meiji Seika, Asteras, DainipponSumitomo, Eli Lilly, Pfizer, Janssen, and Otsuka.

\section{ABBREVIATIONS}

$\begin{array}{ll}\text { ANOVA } & =\text { Analysis of variance analysis } \\ \text { DHEA-S } & =\text { Dehydroepiandsterone-sulfate } \\ \text { NGF } & =\text { Nerve growth factor } \\ \text { NMDA } & =\text { N-methyl-D-aspartate } \\ \text { NORT } & =\text { Novel object recognition test } \\ \text { PCP } & =\text { Phencyclidine } \\ \text { SSRI } & =\text { Selective serotonin reuptake inhibitor }\end{array}$

\section{REFERENCES}

[1] Green, M.F.; Nuechterlein, K.H.; Gold, J.M.; Barch, D.M.; Cohen, J.; Essock, S.; Fenton, W.S.; Frese, F.; Goldberg, T.E.; Heaton, R.K.; Keefe, R.S.; Kern, R.S.; Kraemer, H.; Stover, E.; Weinberger, D.R.; Zalcman, S.; Marder, S.R. Approaching a consensus cognitive battery for clinical trials in schizophrenia: the NIMHMATRICS conference to select cognitive domains and test criteria. Biol. Psychiatry, 2004, 56, 301-307.

[2] Javitt, D.C.; Zukin, S.R. Recent advances in the phencyclidine model of schizophrenia. Am. J. Psychiatry, 1991, 148, 1301-1308.

[3] Olney, J.W.; Farber, N.B. Glutamate receptor dysfunction and schizophrenia. Arch. Gen. Psychiatry, 1995, 52, 998-1007.

[4] Snyder, S.H.; Ferris, C.D. Novel neurotransmitters and their neuropsychitric relevance. Am. J. Psychiatry, 2000, 157, 25-30.

[5] Goff, D.C.; Coyle, J.T. The emerging role of glutamate in the pathophysiology and treatment of schizophrenia. Am. J. Psychiatry, 2001, 158, 1367-1377.

[6] Sawa, A.; Snyder, S.H. Schizophrenia: diverse approaches to a complex disease. Science, 2002, 296, 692-695.

[7] Goff, D.C.; Coyle, J.T. Glutamatergic mechanisms in schizophrenia. Annu. Rev. Pharmacol. Toxicol., 2002, 42, 165-179.

[8] Hashimoto, K.; Fukushima, T.; Shimizu, E.; Komatsu, N.; Watanabe, H.; Shinoda, N.; Nakazato, M.; Kumakiri, C.; Okada, S.; Hasegawa, H.; Imai, K.; Iyo, M. Decreased serum levels of D-serine in patients with schizophrenia: evidence in support of the N-methylD-aspartate receptor hypofunction hypothesis of schizophrenia. Arch. Gen. Psychiatry, 2003, 60, 572-576.

[9] Hashimoto, K.; Okamura, N.; Shimizu, E.; Iyo, M. Glutamate hypothesis of schizophrenia and approach for possible therapeutic drugs. Curr. Med. Chem - CNS Agents, 2004, 4, 147-154.

[10] Hashimoto, K.; Shimizu, E.; Iyo, M. Dysfunction of glia-neuron communication in pathophysiology of schizophrenia. Curr. Psychiatry Rev., 2005, 1, 151-163.

[11] Hashimoto, K.; Hattori, E. Chapter 4. Neurotransmission. In Neurogenetics of Psychiatric Disorders; Akira Sawa and Melvin G. McInnis, Ed., Informa Healthcare, New York, 2007, pp. 81-100.

[12] Hashimoto, K.; Fujita, Y.; Shimizu, E.; Iyo, M. Phencyclidineinduced cognitive deficits in mice are improved by subsequent subchronic administration of clozapine, but not haloperidol. Eur. J. Pharmacol., 2005, 519, 114-117.

[13] Hashimoto, K.; Fujita, Y.; Iyo, M. Phencyclidine-induced cognitive deficits in mice are improved by subsequent subchronic administration of fluvoxamine: role of sigma-1 receptors. Neuropsychopharmacology, 2007, 32, 514-521.

[14] Hashimoto, K.; Fujita, Y.; Ishima, T.; Chaki, S.; Iyo, M. Phencyclidine-induced cognitive deficits in mice are improved by subsequent subchronic administration of glycine transporter-1 inhibitor 
NFPS and D-serine. Eur. Neuropsychopharmacol., 2008, 18, 414421.

[15] Hashimoto, K.; Ishima, T.; Fujita, Y.; Matsuo, M.; Kobashi, T.; Takahagi, M.; Tsukada, H.; Iyo, M. Phencyclidine-induced cognitive deficits in mice are improved by subsequent subchronic administration of the novel selective $\alpha 7$ nicotinic receptor agonist SSR180711. Biol. Psychiatry, 2008, 63, 92-97.

[16] Fujita, Y.; Ishima, T.; Kunitachi, S.; Hagiwara, H.; Zhang, L.; Iyo, M.; Hashimoto, K. Phencyclidine-induced cognitive deficits in mice are improved by subsequent subchronic administration of the antibiotic drug minocycline. Prog. Neuropsychopharmacol. Biol. Psychiatry, 2008, 32, 336-339.

[17] Hagiwara, H.; Fujita, Y.; Ishima, T.; Kunitachi, S.; Shirayama, Y.; Iyo, M.; Hashimoto, K. Phencyclidine-induced cognitive deficits in mice are improved by subsequent subchronic administration of the antipsychotic drug perospirone: role of serotonin $5-\mathrm{HT}_{1 \mathrm{~A}}$ receptors. Eur. Neuropsychopharmacol., 2008, 18, 448-454.

[18] Maurice, T.; Urani, A.; Phan, V.L.; Romieu, P. The interaction between neuroactive steroids and the sigma-1 receptor function: behavioral consequences and therapeutic opportunities. Brain Res. Rev., 2001, 37, 116-132.

[19] Su, T.P.; Hayashi, T. Understanding the molecular mechanism of sigma-1 receptors: towards a hypothesis that sigma-1 receptors are intracellular amplifiers for signal transduction. Curr. Med. Chem., 2003, 10, 2073-2080.

[20] Hayashi, T.; Su, T.P. Sigma-1 receptor chaperones at the ERmitochondrion interface regulate $\mathrm{Ca}^{2+}$ signaling and cell survival. Cell, 2007, 131, 596-610.

[21] Hayashi, T.; Su, T.P. An update on the development of drugs for neuropsychiatric disorders: focusing on the sigma 1 receptor ligand. Expert Opin. Ther. Targets, 2008, 12, 45-58.

[22] Bermack, J.E.; Debonnel, G. The role of sigma receptors in depression. J. Pharmacol. Sci., 2005, 97, 317-336.

[23] Carrasco, J.L.; Sandner, C. Clinical effects of pharmacological variations in selective serotonin reuptake inhibitors: an overview. Int. J. Clin. Pract., 2005, 59, 1428-1434.

[24] Hashimoto, K.; Ishiwata, K. Sigma receptor ligands: possible application as therapeutic drugs and as radiopharmaceuticals. Curr. Pharm. Des., 2005, 12, 3857-3876.

[25] Stahl, S.M. Antidepressant treatment of psychotic major depression: potential role of the sigma receptor. CNS Spectr., 2005, 10, 319-323.
[26] Narita, N.; Hashimoto, K.; Tomitaka, S.; Minabe, Y. Interactions of selective serotonin reuptake inhibitors with subtypes of sigma receptors in rat brain. Eur. J. Pharmacol., 1996, 307, 117-119.

[27] Hirano, K.; Kimura, R.; Sugimoto, Y.; Yamada, J.; Uchida, S.; Kato, Y.; Hashimoto, H.; Yamada, S. Relationship between brain serotonin transporter binding, plasma concentration and behavioural effect of selective serotonin reuptake inhibitors. Br. J. Pharmacol., 2005, 144, 695-702.

[28] Takebayashi, M.; Hayashi, T.; Su, S.P. Nerve growth factorinduced neurite sprouting in PC12 cells involves sigma-1 receptors: implications for antidepressants. J. Pharmacol. Exp. Ther., 2001 303, 1227-1237.

[29] Nishimura, T.; Ishima, T.; Iyo, M.; Hashimoto, K. Potentiation of nerve growth factor-induced neurite outgrowth by fluvoxamine: role of sigma-1 receptors, IP3 receptors and cellular signaling pathways. PLoS ONE, 2008, 3, e2558.

[30] Owens, M.J.; Knight, D.L.; Nemeroff, C.B. Second-generation SSRIs: human monoamine transporter binding profile of escitalopram and R-fluoxetine. Biol. Psychiatry, 2001, 50, 345-350.

[31] Debonnel, G.; de Montigny, C. Modulation of NMDA and dopaminergic neurotransmissions by sigma ligands: possible implications for the treatment of psychiatric disorders. Life Sci., 1996, 58, 721-734.

[32] Weissman, A.D.; Casanova, M.F.; Kleinman, J.E.; London, E.D.; De Souza, E.B. Selective loss of cerebral cortical sigma, but not PCP binding sites in schizophrenia. Biol. Psychiatry, 1991, 29, 4154.

[33] Iyo, M.; Shirayama, Y.; Watanabe, H.; Fujisaki, M.; Miyatake, R.; Fukami, G.; Shiina, A.; Nakazato, M.; Shiraishi, T.; Ookami, T.; Hashimoto, K. Fluvoxamine as a sigma-1 receptor agonist improved cognitive impairments in a patient with schizophrenia. Prog. Neuropsychopharmacol. Biol. Psychiatry, 2008, 32, 10721073.

[34] Ishikawa, M.; Ishiwata, K.; Ishii, K.; Kimura, Y.; Sakata, M.; Naganawa, M.; Oda, K.; Miyatake, R.; Fujisaki, M.; Shimizu, E.; Shirayama, Y.; Iyo, M.; Hashimoto, K. High occupancy of sigma-1 receptors in the human brain after single oral administration of fluvoxamine: A PET study using $\left[{ }^{11} \mathrm{C}\right] \mathrm{SA} 4503$. Biol. Psychiatry, 2007, 62, 878-883.

[35] Hashimoto, K. Sigma-1 receptors and selective serotonin reuptake inhibitors: clinical implications of their relationship. CNS Agents Med. Chem., 2009, in press. 